\title{
Studies in vivo of the effect of unconjugated bilirubin on hepatic phosphorylation and respiration ${ }^{1}$
}

\author{
STEVEN SCHENKER ${ }^{2}$, DAVID W. MCCANDLESS, AND EVA WITTGENSTEIN \\ From the Department of Medicine and Children's Hospital Research Foundation, \\ University of Cincinnati School of Medicine, Cincinnati, Ohio, U.S.A.
}

EDITORIAL SYNOPSIS Unconjugated bilirubin is believed to be toxic to the brain in neonates. Previous work in vitro has shown an important effect on depression of cell respiration and phosphorylation. The present study in vivo fails to confirm these findings in the liver. The exact mechanism of kernicterus remains uncertain.

Studies in vitro of various tissues, including liver, have shown that unconjugated bilirubin at high concentrations uncouples phosphorylation from oxidation (Ernster, 1961). It has accordingly been postulated that the unconjugated bilirubin exerts its cytoxic effect in kernicteric brain (Ernster, 1961), and possibly in intensely hyperpigmented liver (Brown, Grodsky, and Carbone, 1964; Rozdilsky, 1961) in vivo by interfering with the synthesis of adenosine triphosphate (ATP) which is essential for the proper metabolic function of these organs.

The present study provides an assessment of the effect of high levels of unconjugated bilirubin in vivo on hepatic ATP concentration and respiration. The results of this investigation, apparently the first one in living animals, are the basis of this report.

\section{MATERIALS AND METHODS}

EXPERIMENTAL PROCEDURE Non-fasted 1- and 2-day-old guinea-pigs lightly anaesthetized with ethyl ether were infused via the inferior vena cava with $1 \mathrm{ml}$. of a solution of unconjugated bilirubin (Eastman Kodak, Rochester, New York), in physiological saline $(2-5 \mathrm{mg} . / \mathrm{ml}$.), freshly prepared as described previously (Schenker and Schmid, 1964). Control litter mates received either the pigmentfree carrier solution or were sham-injected. Sixty minutes later liver was obtained from both experimental and control animals for measurement of ATP concentration or oxygen consumption and plasma was obtained for determination of total and direct-reading bilirubin concentration. In additional studies similar pigment loads of biosynthesized unconjugated bilirubin- ${ }^{14} \mathrm{C}$ (Ostrow,

'Supported by research grants NB-04894-02 and NB-03443-03 from the National Institute of Neurological Diseases and Blindness, United States Public Health Service.

2John and Mary R. Markle Scholar in Academic Medicine.

Present address: Department of Internal Medicine, Liver and Gastroenterology Unit, University of Texas Southwestern Medical School, Dallas, Texas.
Hammaker, and Schmid, 1961) were infused into newborn guinea-pigs and the distribution of the isotope at the end of 60 minutes was determined in serum, liver, excreted bile, as well as in brain.

To assess the effect of prolonged unconjugated hyperbilirubinaemia on hepatic ATP concentration, the nucleotide was also assayed in livers of Gunn rats, a Wistar strain with hereditary unconjugated hyperbilirubinaemia due to a deficiency of glucuronyl transferase, and with onset of jaundice shortly after birth (Johnson, Sarmiento, Blanc, and Day, 1959). Three groups of these animals were studied: (1) Eight rats, aged 2 days to 9 months, with endogenous hyperbilirubinaemia of less than $10 \mathrm{mg}$./ $100 \mathrm{ml}$.;(2) three adults infused with unconjugated bilirubin in saline three and one half hours previously with resultant serum unconjugated bilirubin levels of over $20 \mathrm{mg} . / 100 \mathrm{ml}$.; (3) two 16-day-old animals with kernicterus. Comparable control studies were performed in non-icteric litter mates of the Gunn rats and in normal Wistar rats of the same age, both uninjected and those infused with bilirubin-free saline. In all animals, except the kernicteric ones, total and direct-reacting plasma bilirubin was measured at the end of the experimental period. In the bilirubin-infused Gunn rats, a pre-injection, and in two instances serial, plasma bilirubin levels were determined on blood collected from the tip of the tail.

METHODS OF ANALYSIS Bilirubin concentration in administered solutions and plasma was measured by the diazo reaction (Malloy and Evelyn, 1937). Since only a terminal sample could be obtained from newborn guinea-pigs without disturbing their circulation, their plasma bilirubin concentration immediately after infusion of the pigment was estimated by dividing the quantity of bilirubin injected by the animal's plasma volume (Schenker and Schmid, 1964) plus the volume of the infusate. In three instances, the validity of the calculation, which falsely assumes equilibration and retention of all the bilirubin in the circulation, was checked by measuring plasma bilirubin concentration 10 minutes after infusing a similar pigment load (allowing equilibration) and 
comparing the results with the calculated value. The measured concentration was about $80 \%$ (range 71.9$91.5 \%$ ) of the predicted value, indicating that the latter was not much above the actual plasma bilirubin level.

For determination of ${ }^{14} \mathrm{C}$ isotope in plasma and tissues, these were prepared for radioassay in a tricarb scintillation counter as described previously (Ostrow et al., 1961). Internal standard was used to correct for quenching and the results converted to disintegrations per minute and expressed as a percentage of injected radioactivity. In a control study, the extraction procedure used (which does not permit separate measurement of unconjugated and conjugated bilirubin fractions) recovered $93 \%$ of radioactivity added to liver in the form of unconjugated bilirubin-14 $\mathrm{C}$ saline solution.

The ATP was measured on the rapidly frozen liver by the luciferin-luciferase-luminescence method (Schenker and O'Donnell, 1965). All assays were carried out in duplicate and the results averaged. The technique and its validation and reproducibility under these experimental conditions have been described in a prior publication (Schenker and O'Donnell, 1965). The ATP concentration was expressed both as micromoles per gram liver, wet weight, and per gram liver protein, the latter having been determined for each specimen by the method of Lowry, Rosebrough, Farr, and Randall (1951). Earlier studies (Schenker and O'Donnell, 1965) have established that sex of the animals, the site of liver sampling, and the presence or duration (after five minutes) of ether anaesthesia have no effect on hepatic ATP levels, hence these factors were not separately assessed. Addition in vitro of a quantity of unconjugated bilirubin, calculated to be present in liver from isotope studies, to newborn guinea-pig liver, failed to affect the hepatic ATP concentration as compared with adjacent hepatic tissue assayed without added bile pigment.

For determination of oxygen consumption, a section of liver weighing about $1.2 \mathrm{~g}$. was rapidly excised, weighed, and finely homogenized by hand with 5 volumes/weight of $0.04 \mathrm{M} \mathrm{KH}_{2} \mathrm{PO}_{4}$ buffer adjusted to $p \mathrm{H} 7.6$ with $0.1 \mathrm{~N}$ $\mathrm{NaOH}$. The above procedure was carried out in a precooled glass homogenizer maintained throughout in crushed ice and the timing was set at exactly one and one-half minutes from tissue excision to the start of homogenation which was completed in another four and one-half minutes. At this time $1.4 \mathrm{ml}$. of the homogenate was pipetted rapidly into a prechilled Warburg flask to which was added another $0.4 \mathrm{ml}$. of phosphate buffer and $0.2 \mathrm{ml}$. of $10 \mathrm{mg} . / \mathrm{ml}$. glucose. In the centre well were placed $0.2 \mathrm{ml}$. of $10 \% \mathrm{KOH}$ and a strip of folded filter paper to enhance the absorption of liberated carbon dioxide. The flasks, placed on ice, were gassed for five minutes with pure oxygen and after an equilibration of 10 minutes, oxygen consumption was measured by standard Warburg manometry at 10-minute intervals for one hour. The incubation was carried out at $37^{\circ} \mathrm{C}$., at 50 strokes per minute. All studies were carried out in triplicate, the results averaged and expressed in microlitres $(\mu 1$.) of oxygen consumed/mg. tissue (wet weight)/1 hour. In most instances the protein concentration of the experimental and control homogenates was determined and the results also expressed on basis of liver protein.
Demineralized distilled water was used for preparation of all solutions and the washing of glassware.

ANCILLARY STUDIES To assess interlitter mate variability with respect to hepatic oxygen consumption, this was investigated in two litters of three and four 1-day-old guinea-pigs, uninjected but anaesthetized with ether for 60 minutes. Similarly, the effect of intravenous saline on hepatic respiration was studied in injected and uninjected newborn litter mate guinea-pigs.

In three instances, the effect of unconjugated bilirubin in vitro on hepatic oxygen consumption was determined. For this the incubation system described above was employed with the following modifications: all liver tissue was obtained from uninjected 1-day-old guinea-pigs; $30 \mathrm{mg}$. of commercial bilirubin was dissolved in $0.3 \mathrm{ml}$. of $0.1 \mathrm{~N} \mathrm{NaOH}$ and $9.6 \mathrm{ml}$. of phosphate buffer and 0.2 $\mathrm{ml}$. of the final solution (containing $600 \mu \mathrm{g}$. of bilirubin) was added to the Warburg flask immediately before incubation; bilirubin-free buffer was added to the control flasks containing liver homogenates. This incubation medium was closely patterned after one used previously by Waters and Bowen (1955) to show a depressing effect of unconjugated bilirubin in vitro on rat brain homogentes.

\section{RESULTS}

The effect of unconjugated hyperbilirubinaemia on hepatic ATP concentration of newborn guinea-pigs is presented in Table I. The plasma unconjugated bilirubin levels achieved during the experimental period were well within, and in some instances in excess of, the range of values reported for kernicteric infants (Hsia, Allen, Gellis, and Diamond, 1952) and those used in vitro to demonstrate a depressant effect of the pigment on tissue phosphorylation (Ernster, 1961). Despite this, hepatic ATP levels, both on the basis of tissue wet weight and its protein concentration, were similar in bilirubin-infused and control litter mates. In addition, the nucleotide concentration in the icteric group closely correspond to that obtained in another series of 301 - and 2-day-old control guinea-pigs (Table I). In the bilirubininfused animals there was no correlation between the height of the initial or terminal plasma bilirubin level and the ATP concentration in liver.

A comparable degree of hyperbilirubinaemia of one hour's duration likewise failed to affect the hepatic oxygen consumption of newborn guineapigs (Table II). Comparison of rates of oxygen consumption (at 10-minute intervals) also revealed similar values in the experimental and control groups. The inter-litter mate variation in hepatic oxygen consumption among normal sham-injected newborn guinea-pigs was $\pm 10 \%$ and this was unaffected by the infusion of pigment-free saline. Addition of unconjugated bilirubin (final concentration of 30 $\mathrm{mg} . / 100 \mathrm{ml}$. medium) to liver homogenates in the 
TABLE I

EFFECT OF UNCONJUGATED HYPERBILIRUBINAEMIA FOR 60 MINUTES ON HEPATIC ATP LEVELS OF NEWBORN GUINEA-PIGS

\begin{tabular}{|c|c|c|c|c|c|c|c|c|c|}
\hline \multirow{3}{*}{$\begin{array}{l}\text { Litter } \\
\text { No. }\end{array}$} & \multirow{3}{*}{$\begin{array}{l}\text { Animal } \\
\text { Age } \\
\text { (days) }\end{array}$} & \multicolumn{2}{|c|}{ Bilirubin Administered } & \multirow{2}{*}{\multicolumn{2}{|c|}{$\begin{array}{l}\text { Total Serum Bilirubin } \\
(\mathrm{mg} . / 100 \mathrm{ml} .)^{2}\end{array}$}} & \multicolumn{4}{|c|}{ Hepatic ATP Level } \\
\hline & & \multirow[t]{2}{*}{$m g$. } & \multirow{2}{*}{$\begin{array}{l}\text { ug./g. } \\
\text { Body Weight }\end{array}$} & & & \multicolumn{2}{|c|}{ Bilirubin-infused } & \multicolumn{2}{|l|}{ Control $^{3}$} \\
\hline & & & & Start ${ }^{1}$ & End & $\begin{array}{l}\mu M / g . \text { Liver } \\
\text { (wet weight) }\end{array}$ & $\begin{array}{l}\mu M / g . \text { Liver } \\
\text { Protein }\end{array}$ & $\begin{array}{l}\mu M / g . \text { Liver } \\
\text { (wet weight) }\end{array}$ & $\begin{array}{l}\mu M / g . \text { Liver } \\
\text { Protein }\end{array}$ \\
\hline \multirow[t]{2}{*}{$\begin{array}{l}1 \\
2 \\
3 \\
4 \\
5 \\
6 \\
7\end{array}$} & $\begin{array}{l}1 \\
1 \\
1 \\
2 \\
2 \\
2 \\
2\end{array}$ & $\begin{array}{l}4 \cdot 6 \\
5 \cdot 0 \\
7 \cdot 0 \\
2 \cdot 5 \\
2 \cdot 5 \\
2 \cdot 8 \\
4 \cdot 0\end{array}$ & $\begin{array}{l}49 \cdot 5 \\
53 \cdot 2 \\
75 \cdot 3 \\
23 \cdot 4 \\
27 \cdot 2 \\
30 \cdot 4 \\
45 \cdot 5\end{array}$ & $\begin{array}{r}73 \cdot 0 \\
78 \cdot 7 \\
111 \cdot 1 \\
35 \cdot 2 \\
40 \cdot 3 \\
45 \cdot 2 \\
66 \cdot 4\end{array}$ & $\begin{array}{r}25 \cdot 5 \\
62 \cdot 0 \\
56 \cdot 0 \\
14 \cdot 4 \\
8 \cdot 8 \\
11 \cdot 0 \\
18 \cdot 0\end{array}$ & $\begin{array}{l}2.42 \\
3.28 \\
3.91 \\
3.98 \\
3 \cdot 18 \\
3.33 \\
2.81\end{array}$ & $\begin{array}{l}17 \cdot 06 \\
17 \cdot 20 \\
27 \cdot 59 \\
21 \cdot 63 \\
18 \cdot 19 \\
21 \cdot 68 \\
14 \cdot 37\end{array}$ & $\begin{array}{l}2 \cdot 82 \\
3 \cdot 14 \\
3 \cdot 68 \\
3 \cdot 73 \\
3 \cdot 02 \\
3 \cdot 04^{4} \\
2 \cdot 64^{4}\end{array}$ & $\begin{array}{l}23 \cdot 22 \\
18 \cdot 51 \\
24 \cdot 57 \\
18 \cdot 54 \\
21 \cdot 78 \\
19 \cdot 66^{4} \\
14 \cdot 35^{4}\end{array}$ \\
\hline & $\begin{array}{l}\text { Mean } \\
\pm \text { S.D. }\end{array}$ & 4.06 & Hepatic ATP level, mean \pm S.D. of control guinea-pigs ${ }^{5}$ & evel, mea & D. of $\mathrm{c}$ & $\begin{array}{r}3.27 \\
\pm 0.52\end{array}$ & $\begin{array}{c}19 \cdot 67 \\
\pm 4.03 \\
18 \text { one-day-old } \\
12 \text { two-day-ol }\end{array}$ & $\begin{array}{c}\quad 3 \cdot 15 \\
\pm 0 \cdot 38 \\
\text { d guinea-pigs } \\
\text { Id guinea-pigs }\end{array}$ & $\begin{array}{c}20 \cdot 12 \\
\pm 3 \cdot 11 \\
20 \cdot 61 \\
3 \cdot 26 \\
19 \cdot 73 \\
\pm 3.46\end{array}$ \\
\hline
\end{tabular}

${ }^{1}$ Bilirubin concentration at the start of the experiment is estimated from the quantity of pigment infused and the animals' plasma volume (4) plus the volume of infusate. Equilibration of the bilirubin in plasma and lack of diffusion into tissues are assumed (see Materials and Methods). 'Only a trace or no direct-reacting bilirubin was detected.

${ }^{3}$ Control animals, unless otherwise specified, were sham-operated litter mate guinea-pigs (see Materials and Methods). Their serum at sacrifice revealed only a trace or no detectable bilirubin.

Animals infused with $1 \mathrm{ml}$. of pigment-free physiological saline.

${ }^{5}$ The data for these normal uninjected unoperated newborn guinea-pigs have been included in a prior publication (Amer. J. Physiol., 208, 573, 1965). They have been here adjusted downward by $16.47 \%$ to correct for products of crystallization present in the previously used standard crystalline ATP.

TABLE II

EFFECT OF UNCONJUGATED HYPERBILIRUBINAEMIA ON HEPATIC OXYGEN CONSUMPTION OF NEWBORN GUINEA-PIGS

\begin{tabular}{|c|c|c|c|c|c|c|c|}
\hline \multirow[t]{2}{*}{ Litter No. } & \multirow{2}{*}{$\begin{array}{l}\text { Animal Age } \\
(\text { days })\end{array}$} & \multicolumn{2}{|c|}{ Bilirubin Administered ${ }^{1}$} & \multicolumn{2}{|c|}{$\begin{array}{l}\text { Total Serum Bilirubin } \\
(\mathrm{mg} . / 100 \mathrm{ml} .)\end{array}$} & \multicolumn{2}{|c|}{$\begin{array}{l}\text { Hepatic Oxygen Consumption } \\
(\mu l . / m g . \text { liver } / h r .)^{4}\end{array}$} \\
\hline & & $m g$. & $\begin{array}{l}\mu \mathrm{g} \cdot / \mathrm{g} . \text { Body } \\
\text { Weight }\end{array}$ & Start $^{2}$ & At One Hour ${ }^{3}$ & Bilirubin-infused & Control $^{5}$ \\
\hline $\begin{array}{l}1 \\
2 \\
3 \\
4 \\
5 \\
6 \\
7 \\
8\end{array}$ & $\begin{array}{l}1 \\
2 \\
2 \\
2 \\
2 \\
2 \\
2 \\
2 \\
\text { Mean } \\
+ \text { S.D. }\end{array}$ & $\begin{array}{l}4 \cdot 1 \\
2 \cdot 4 \\
3 \cdot 6 \\
4 \cdot 8 \\
2 \cdot 5 \\
4 \cdot 0 \\
2 \cdot 6 \\
5 \cdot 4 \\
3.68\end{array}$ & $\begin{array}{l}47 \cdot 7 \\
32 \cdot 4 \\
33 \cdot 6 \\
38 \cdot 4 \\
39 \cdot 1 \\
40 \cdot 8 \\
42 \cdot 6 \\
74 \cdot 0 \\
43 \cdot 58\end{array}$ & $\begin{array}{c}69.5 \\
46.0 \\
50.7 \\
59.0 \\
53.8 \\
60.7 \\
58.0 \\
104.7 \\
62.80\end{array}$ & $\begin{array}{l}23 \cdot 0 \\
28 \cdot 0 \\
10 \cdot 0 \\
25 \cdot 0 \\
14 \cdot 0 \\
20 \cdot 0 \\
24 \cdot 2 \\
57 \cdot 0 \\
25 \cdot 14\end{array}$ & $\begin{array}{c}1.11 \\
1.26 \\
1.01 \\
0.76 \\
0.61 \\
0.73 \\
0.85 \\
0.49 \\
0.853 \\
\pm 0.244\end{array}$ & $\begin{array}{c}0.88 \\
1.01 \\
1.14 \\
0.61 \\
0.37 \\
0.95 \\
1.14 \\
0.51 \\
0.826 \\
+0.275\end{array}$ \\
\hline
\end{tabular}

${ }^{1}$ The unconjugated bilirubin was administered in $1 \mathrm{ml}$. of physiological saline.

'See pertinent footnote to Table I.

3only a trace or no direct-reacting bilirubin was detected.

The hepatic oxygen consumption is expressed in terms of tissue wet weight. Protein determination on tissue homogenates and calculation of data on that basis yielded similar results.

${ }^{5}$ Control animals were infused with $1 \mathrm{ml}$. of pigment-free physiological saline and at sacrifice the serum revealed only a trace or no detectable bilirubin.

same incubation system, however, resulted in a $30-50 \%$ decrease in oxygen consumption, as compared with litter mate liver assayed without added pigment.

Table III shows the distribution of ${ }^{14} \mathrm{C}$ radioactivity in newborn guinea-pig plasma, liver, and bile after administration of unconjugated bilirubin${ }^{14} \mathrm{C}$ in amounts comparable to those employed above. The quantity of radioactivity retained in the circulation was obtained from the product of the isotope concentration in plasma and the plasma volume
(Schenker and Schmid, 1964). In two instances, plasma bilirubin was measured also by the diazo reaction and the quantity retained in plasma, as a percentage of injected pigment, correlated well with calculations based on radioassay. Only traces of direct-reading bilirubin were found in plasma of bilirubin-infused newborn guinea-pigs. The mean isotope at the end of 60 minutes in plasma and liver, disregarding the small contribution of trapped intrahepatic plasma (Grodsky, Contopoulos, Fanska, and Carbone, 1963) and bile (Barber-Riley, 1963) 
TABLE III

DISTRIBUTION OF ADMINISTERED UNCONJUGATED BILIRUBIN-14C IN NEWBORN GUINEA-PIGS

\begin{tabular}{|c|c|c|c|c|c|}
\hline \multirow{2}{*}{$\begin{array}{l}\text { Animal } \\
\text { Age } \\
\text { (days) }\end{array}$} & \multicolumn{2}{|c|}{$\begin{array}{l}\text { Bilirubin-14 C } \\
\text { Administered }\end{array}$} & \multicolumn{3}{|c|}{$\begin{array}{l}\text { Percentage Administered Radio- } \\
\text { activity }^{1}\end{array}$} \\
\hline & mg. & $\begin{array}{l}\mu \mathrm{g} \cdot / \mathrm{g} . \text { Body } \\
\text { Weight }\end{array}$ & $\begin{array}{l}\text { Retained } \\
\text { in } \\
\text { Plasma }\end{array}$ & $\begin{array}{l}\text { Retained } \\
\text { in } \\
\text { Liver }^{2}\end{array}$ & $\begin{array}{l}\text { Excreted } \\
\text { in } \\
\text { Bile }\end{array}$ \\
\hline $\begin{array}{c}1^{3} \\
1^{3} \\
1 \\
1 \\
2 \\
2^{3} \\
2^{3} \\
\text { Mean }\end{array}$ & $\begin{array}{l}2 \cdot 3 \\
2 \cdot 3 \\
5 \cdot 0 \\
5 \cdot 0 \\
1 \cdot 4 \\
3 \cdot 2 \\
4 \cdot 1 \\
3 \cdot 33\end{array}$ & $\begin{array}{l}21 \cdot 3 \\
23 \cdot 7 \\
39 \cdot 1 \\
41 \cdot 3 \\
16 \cdot 9 \\
34 \cdot 4 \\
44 \cdot 1 \\
31 \cdot 54\end{array}$ & $\begin{array}{r}12.1 \\
7.4 \\
31.9 \\
32.2 \\
8.8 \\
35.6 \\
38.9 \\
23.84\end{array}$ & $\begin{array}{r}21 \cdot 6 \\
30 \cdot 8 \\
27.9 \\
21 \cdot 7 \\
8.6 \\
19 \cdot 4 \\
19 \cdot 1 \\
21 \cdot 31\end{array}$ & $\begin{array}{r}24 \cdot 7 \\
22 \cdot 4 \\
8 \cdot 0 \\
6 \cdot 8 \\
43 \cdot 0 \\
8 \cdot 9 \\
9 \cdot 3 \\
17 \cdot 59\end{array}$ \\
\hline
\end{tabular}

${ }^{1}$ Radioassay carried out 60 minutes after administration of labelled bilirubin.

'Estimate of total bilirubin. Liver extracted for radioassay with $1 \mathrm{~N} \mathrm{NaOH}$ (see Materials and Methods). No correction was made for the plasma and bile trapped in liver.

${ }^{3}$ Litter mates.

which, extrapolating from rat data, constitute less than $1 \%$ of injected label, was 23.8 and $21 \cdot 3 \%$ of injected radioactivity, respectively. Inasmuch as liver, assessed in nine animals, and plasma constitute, respectively, 4.3 and $5.7 \%$ of newborn guinea-pig weight, it appears that the isotope concentration in both compartments was similar on average.

A mean of $17.6 \%$ of infused labelled bilirubin, equal to $441.6 \mu \mathrm{g}$. of the pigment, was excreted in bile in one hour. In separate experiments with newborn guinea-pigs, provided with external biliary fistulae, it was established that virtually all of the freshly collected bilirubin in bile reacted directly with the diazo reagent. While biliary excretion of the bilirubin was determined only from isotope content of the gall bladder and gastrointestinal tract, radio- assay of bile collected by external biliary drainage has confirmed the validity of the present technique (Schenker and Schmid, 1964). In addition, similar studies in adult guinea-pigs, with concurrent estimation of biliary bilirubin $-{ }^{14} \mathrm{C}$, have shown that at least $75 \%$ of biliary ${ }^{14} \mathrm{C}$ radioactivity is excreted in the form of the labelled conjugated bilirubin (Schenker, Dawber and Schmid, 1964). In this study, only traces of the isotope were found in the brain of newborn guinea-pigs.

As shown in Table IV, prolonged endogenous unconjugated hyperbilirubinaemia, albeit low grade, also had no depressant effect on Gunn rat hepatic ATP concentration. In addition, three bilirubininfused adult Gunn rats with plasma bilirubin levels of 25 to $30 \mathrm{mg}$. $/ 100 \mathrm{ml}$. at the end of three and onehalf hours (and higher in the intervening period) and two kernicteric animals likewise manifested hepatic ATP levels comparable to those of the age-matched controls. The ATP data in all Gunn rats agree closely with those obtained in normal Wistar rats of the same age (Schenker and O'Donnell, 1965).

\section{DISCUSSION}

Previous investigations in vitro have shown conclusively that unconjugated bilirubin depresses phosphorylation and, to a lesser extent, respiration of liver mitochondria (Ernster, 1961) and the latter effect has also been shown in liver homogenates in the present study. By contrast, hyperbilirubinaemic liver of newborn guinea-pigs and adult Gunn rats infused with unconjugated bilirubin and of Gunn rats with endogenous hyperbilirubinaemia have been shown in this investigation to sustain normal oxygen consumption in newborn guinea-pigs (Table II)

TABLE IV

EFFECT OF ENDOGENOUS UNCONJUGATED HYPERBILIRUBINAEMIA ON HEPATIC ATP OF GUNN RATS

\begin{tabular}{|c|c|c|c|c|c|c|}
\hline \multirow[t]{3}{*}{ Litter No. } & \multirow{3}{*}{$\begin{array}{l}\text { Animal Age } \\
\text { (days) }\end{array}$} & \multirow{3}{*}{$\begin{array}{l}\text { Total Serum } \\
\text { Bilirubin }{ }^{\mathbf{2}} \\
(\mathrm{mg} . / 100 \mathrm{ml}\end{array}$} & \multicolumn{4}{|c|}{ Hepatic ATP Levels } \\
\hline & & & \multicolumn{2}{|l|}{ Gunn Rats } & \multicolumn{2}{|l|}{ Control $^{2}$} \\
\hline & & & $\begin{array}{l}\mu M / g . \text { Liver } \\
\text { (wet weight) }\end{array}$ & $\begin{array}{l}\mu M / g . \text { Liver } \\
\text { Protein }\end{array}$ & $\begin{array}{l}\mu M / g . \text { Liver } \\
\text { (wet weight) }\end{array}$ & $\begin{array}{l}\mu M / g . \text { Liver } \\
\text { Protein }\end{array}$ \\
\hline 1 & 2 & $2 \cdot 3^{3}$ & 3.45 & $25 \cdot 54$ & $\begin{array}{l}3.09 \\
3 \cdot 16\end{array}$ & $\begin{array}{l}18 \cdot 30 \\
18 \cdot 32\end{array}$ \\
\hline & & & 3.85 & 25.42 & 3.93 & $24 \cdot 54$ \\
\hline 2 & 6 & $2 \cdot 0^{3}$ & $\begin{array}{l}3 \cdot 11 \\
3 \cdot 30\end{array}$ & $\begin{array}{l}20 \cdot 82 \\
23 \cdot 50\end{array}$ & $\begin{array}{l}3.09 \\
2.56\end{array}$ & $\begin{array}{l}22 \cdot 25 \\
23 \cdot 58\end{array}$ \\
\hline 3 & 9 & 9.0 & 2.96 & $17 \cdot 33$ & 2.82 & $20 \cdot 21$ \\
\hline 4 & 25 & $5 \cdot 5$ & $3 \cdot 22$ & 17.02 & $\begin{array}{l}3 \cdot 18 \\
3 \cdot 37\end{array}$ & $\begin{array}{l}20.51 \\
22.87\end{array}$ \\
\hline 5 & Adult & $\begin{array}{l}7 \cdot 0 \\
4 \cdot 5\end{array}$ & $\begin{array}{l}3.99 \\
3.93\end{array}$ & $\begin{array}{l}19.91 \\
21.73\end{array}$ & 4.08 & $19 \cdot 20$ \\
\hline & $\begin{array}{l}\text { Mean } \\
\pm \text { S.D. }\end{array}$ & $5 \cdot 1$ & $\begin{array}{r}3.48 \\
\pm 0.38\end{array}$ & $\begin{array}{r}21.41 \\
\pm 3.08\end{array}$ & $\begin{array}{r}3.25 \\
\pm 0.34\end{array}$ & $\begin{array}{r}21.09 \\
\pm 2.18\end{array}$ \\
\hline
\end{tabular}

${ }^{1}$ No direct-reacting bilirubin was detected.

'Controls were heterozygous litter mates without hyperbilirubinaemia.

specimens pooled from these animals. 
and normal (control) ATP levels in all three groups of animals (Tables I, IV). Thus there was a difference in the effects in vivo and in vitro of unconjugated bilirubin on liver, although the effects in vitro were noted at lower bilirubin levels $(12 \mathrm{mg} . / 100 \mathrm{ml}$. medium) and during a shorter time (10-15 minutes) (Ernster, 1961) than were employed in most of the present studies. These differences could be due both to a higher concentration of the pigment in hepatic mitochondria in the experiments in vitro, or to the retention of some protective substance(s) or compensatory mechanism for phosphorylation in the living animal. The intrahepatic concentration in vivo of labelled bilirubin in the present study (Table III) was similar in serum and in the liver homogenatebilirubin incubation media. This essentially equal liver/serum bilirubin concentration gradient agrees with results obtained in adult Gunn rats (Schmid and Hammaker, 1963) and in normal rats infused with Tm-exceeding loads of unconjugated bilirubin (Billing, Maggiore, and Cartter, 1963). In normal adult rats given smaller loads of tritiated bilirubin a higher concentration of the labelled pigment was found in liver as a whole, but only $5.5 \%$ of total hepatic isotope was recovered from lysosome-free mitochondria which normally constitute about $18 \%$ of liver weight (Brown et al., 1964). Since, however, a similarly low intramitochondrial concentration of the pigment was found in liver homogenates in vitro after addition of a comparable quantity of bilirubin (Brown et al., 1964), these facts, which do not discriminate between unconjugated and conjugated bilirubin, may not explain our results. No comparable assessments have been made of the unconjugated fraction in lysosome-free liver mitochondria of newborn animals given large pigment loads or of liver homogenates in vitro, employing high bilirubin concentrations. Therefore the first postulate, though a likely one, remains unproven. Regarding the second possibility, albumin and various inorganic ions in vitro inhibit the cellular toxic effect of unconjugated bilirubin (Ernster, 1961). The role of such factor(s) or of possible compensatory mechanism(s) for generating high energy phosphates in vivo, in the presence of high concentrations of unconjugated bilirubin, is entirely speculative.

Nevertheless it is evident from this study that unconjugated hyperbilirubinaemia, comparablein degreeand duration to that employed in vitro, did not impair the hepatic respiratory mechanism or phosphorylation in viable animals. In addition, prolonged lower-grade hyperbilirubinaemia similar to that observed in many human diseases likewise failed to affect hepatic ATP levels, in contrast to kernicteric Gunn rat brain wherein we have recently noted a decreased ATP concentration in those areas which were hyper- pigmented and appeared to be functionally damaged (Schenker, McCandless, and Wittgenstein, 1964). Comparison of respective susceptibility of liver and brain in vivo to the cytotoxic effects of unconjugated bilirubin is hampered by the difference in the experimental design for the two studies and lack of accurate measurements of bilirubin concentration in kernicteric brain. Visual estimation of bilirubin content in kernicteric Gunn rat brain, coupled with extraction of its pigment with chloroform in preliminary studies, and the finding of low cerebral bilirubin levels in newborn puppies infused with lethal loads of unconjugated bilirubin (Waters, 1961), suggest that the decline in ATP in hyperpigmented kernicteric brain occurs at bilirubin levels lower than those found innocuous for the liver. This apparent susceptibility of the brain to unconjugated bilirubin, for which no specific explanation is available, is also seen in the differential effect of various anaesthetic agents on cerebral and hepatic respiration (Hoech, Matteo, Fink, and Hoskins, 1965). It has recently been suggested that the selective toxicity of bilirubin for the central nervous system in vivo may be related to the less effective protective effect of albumin at that site (Menkin, Barrett, Swarm, and Berlin 1966).

Two comments are pertinent to the interpretation of the hepatic ATP data presented. (1) Hepatic phosphorylation in this study was assessed from measurement of an ATP concentration representing the result of formation and utilization of the nucleotide. The normal hepatic respiration and structure (light microscopy) in the bilirubin-infused guinea-pigs suggest that the normal nucleotide level observed was not maintained by a compensatory decrease in its utilization. In fact, intrahepatic metabolism of bilirubin, although slow in the newborn guineapig (Table III) (Schenker and Schmid, 1964), is believed to be an energy-requiring process (Combes, 1964; Dutton, 1961) and theoretically should augment ATP consumption. It is, therefore, especially noteworthy that even under these circumstances, the newborn animals, with a limited complement of enzymes required for oxidative phosphorylation (Dallman and Schwartz, 1964), were able to maintain control levels of the nucleotide. (2) Hepatic ATP in vivo is generated in mitochondria which are evenly distributed in liver (Lehninger, 1964), and sampling of various parts of liver, indeed, gives reproducible ATP values (Schenker and O'Donnell, 1965). This technique, however, does not preclude the possibility that a small, but biologically important, structural or functional intramitochondrial pool of the nucleotide may be selectively depleted by the unconjugated bilirubin, although this hypothesis is not supported by the findings of normal 
hepatic function, except for bilirubin metabolism, in certain states of benign prolonged high-grade unconjugated hyperbilirubinaemia (Schmid, 1960).

\section{SUMMARY}

It has been suggested on the basis of studies in vitro that unconjugated bilirubin in high concentrations is cytotoxic by uncoupling oxidative phosphorylation, thus interfering with the intracellular synthesis of adenosine triphosphate. In the present study, this concept has been tested in vivo for liver by measuring hepatic ATP concentration and respiration in animals with high-grade unconjugated hyperbilirubinaemia. At plasma levels of unconjugated bilirubin, similar in magnitude and duration to those employed in studies in vitro, no significant effects on hepatic ATP or respiration were observed in vivo. The present data suggest that unconjugated hyperbilirubinaemia observed in human disease states does not interfere with hepatic oxidative phosphorylation.

\section{REFERENCES}

Barber-Riley, G. (1963). Measurement of capacity of biliary tree in rats. Amer. J. Physiol., 205, 1122-1126.

Billing, B. H., Maggiore, Q., and Cartter, M. A., (1963). Hepatic transport of bilirubin. Ann. N.Y. Acad. Sci., 111, 319-325.

Brown, W. R., Grodsky, G. M., and Carbone, J. V. (1964). Intracellular distribution of tritiated bilirubin during hepatic uptake and excretion. Amer. J. Physiol., 207, 1237-1241.

Combes, B. (1964). Excretory function of the liver. In The Liver, edited by C. Rouiller, pp. 1-35. Academic Press, New York, vol. 2.

Dallman, P. R., and Schwartz, H. C. (1964). Cytochrome concentrations during rat and guinea pig development. Pediatrics, 33, 106-110.

Dutton, G. J. (1961). The mechanism of glucuronide formation. In Kernicterus, edited by A. Sass-Kortsak, pp. 88-93. University of Toronto Press.

Ernster, L. (1961). The mode of action of bilirubin on mitochondria. In Kernicterus, edited by A. Sass-Kortsak, pp. 174-192. University of Toronto Press.
Grodsky, G. M., Contopoulos, A. N., Fanska, R., and Carbone, J. V. (1963). Distribution of bilirubin- $\mathrm{H}^{3}$ in the fetal and maternal rat. Amer. J. Physiol., 204, 837-841.

Hoech, G. P. Jr., Matteo, R. S., Fink, B. R., and Hoskins, F. C. G. (1965). Irreversible inhibition of brain slice respiration by gaseous anaesthetics compared to effects on heart and liver. Fed. Proc., 24, 394, 1467 (abstr.)

Hsia, D. Y. Y., Allen, F. H., Jr., Gellis, S. S., and Diamond, L. K. (1952). Erythroblastosis fetalis. VIII. Studies of serum bilirubin in relation to kernicterus. New Engl. J. Med., 247, 668-671.

Johnson, L., Sarmiento, F., Blanc, W. A., and Day, R. (1959). Kernicterus in rats with an inherited deficiency of glucuronyl transferase. Amer. J. Dis. Child., 97, 591-608.

Lehninger, A. L. (1964). The Mitochondrion, pp. 16-40. Benjamin, Inc., New York.

Lowry, O. H., Rosebrough, N. J., Farr, A. L., and Randall, R. J. (1951). Protein measurement with the folin phenol reagent. J. biol. Chem., 193, 265-275.

Malloy, H. T., and Evelyn, K. A. (1937). The determination of bilirubin with the photoelectric colorimeter. Ibid., 119, 481490.

Menkin, M., Barrett, P.V.D., Swarm, R. L., and Berlin, N. I. (1966). Bilirubin encephalopathy. Development of experimental model. Clin. Res., 14, (abstr.), p. 65.

Ostrow, J. D., Hammaker, L., and Schmid, R. (1961). The preparation of crystalline bilirubin-C14. J. clin. Invest., 40, 1442-1452.

Rozdilsky, B. (1961). Experimental studies on the toxicity of bilirubin. In Kernicterus, edited by A. Sass-Kortsak, pp. 161-166. University of Toronto Press.

Schenker, S., Dawber, N. H., and Schmid, R. (1964). Bilirubin metabolism in the fetus. J. clin. Invest., 43, 32-39.

-, McCandless, D. W., and Wittgenstein, E. (1964). Hepatic and cerebral adenosine triphosphate (ATP) in unconjugated hyperbilirubinemia and kernicterus. J. Lab. clin. Med., 64, 1002 (abstr.).

- O'Donnell, J. F. (1965). Effect of maturation on hepatic adenosine triphosphate. Amer. J. Physiol., 208, 628-632.

-, and Schmid, R. (1964). Excretion of $C^{14}$-bilirubin in newborn guinea pigs. Proc. Soc. exp. Biol. (N.Y.), 115, 446-448.

Schmid, R. (1960). Hyperbilirubinemia. In The Metabolic Basis of Inherited Disease, edited by J. B. Stanbury, J. B. Wyngaaden, and D. S. Fredrickson, pp. 245-256. McGraw-Hill, New York.

- and Hammaker, L. (1963). Metabolism and disposition of $\mathrm{C}^{14}$-bilirubin in congenital nonhemolytic jaundice. J. clin. Invest., 42, 1720-1734.

Waters, W. J. (1961). The protective action of albumin in bilirubin toxicity in newborn puppies. In Kernicterus, edited by A. Sass-Kortsak, pp. 219-221. University of Toronto Press.

- and Bowen, W. R. (1955). Bilirubin encephalopathy: Studies related to cellular respiration. Amer. J. Dis. Child., 90,603 (abstr.). 